\title{
スポーツスポンサーシップ研究概説
}

\author{
Overview of Sport Sponsorship Research
}

\section{辻 洋右}

琉球大学

\section{Abstract}

The purpose of this paper is to provide an overview of sport sponsorship with a focus on its research areas. Sport sponsorship has seen a tremendous growth in the past couple of decades with companies spending over 46 billion US dollars in 2010 worldwide (IEG, 2011). With this growth, this specific medium has caught the attention of both practitioners and academicians with respect to its nature and its effectiveness among others. The paper aims to provide the definition of and the uniqueness of the medium, explains some of the theoretical frameworks of past sport sponsorship research, and makes suggestions for future research.

Key words: sport marketing, sport sponsorship, sponsorship effectiveness

キーワード : スポーツマーケティング、スポーツスポンサーシップ、スポンサージップ効果

\section{連絡先 :}

辻洋右

琉球大学

観光産業科学部産業経営学科

干 903-0213 沖縄県西原町千原 1 番地
Address Correspondence to:

Yosuke Tsuji, University of the Ryukyus

1 Senbaru Nishihara, Okinawa 903-0213, Japan

E-mail: y-tsuji@tm.u-ryukyu.ac.jp 


\section{はじめに}

近年のスポンサーシップ産業は目覚ましい発展 を遂げている。米国 IEG 社の発表によると 2010 年度の全世界における企業のスポンサーシップ に対する費用は、未曾有の金融危機による世界的 大不況にも関わらず、2009 年度より $5.2 \%$ 増え、 463 億米ドルであった（IEG, 2011）。また、アジ アにおける企業のスポンサーシップ支出は 2009 年度より $5 \%$ 成長し、106 億米ドルに達したと 発表している。北米では 2009 年度に唯一のマイ ナス成長（一 $0.6 \%)$ を遂げたが、2010 年度に は回復し（3.9\%)、175 億米ドルを記録している。 IEG 社の発表によると、企業のスポンサーシップ 投資は少なくとも過去 20 年は右肩上がりで成長 し続けている (Cornwell, 2008; IEG, 2011; Lough, et al., 2000; Marketing fact book, 2005)。その中で も企業のスポーツ組織へのスポンサーシップ投資 は、全体の約 70\%を占め（その他は絵画、慈善 運動、フェスティバル、ツアー等)、実務家や研 究者より注目を集めてきた (IEG, 2011; Lough et al., 2000; Pope, 1998; Sandler and Shani, 1993)。よ って、本論文ではスポーツに焦点をあて、主に企 業側から見たスポーツスポンサーシップの意義、 価值、必要性などを確認し、その研究を紹介する。

\section{スポーツスポンサーシップの定義}

スポーツスポンサーシップとは、スポーツの活 動において企業が商業利用する権利の見返りに対 して金銭の支払いや製品・サービス提供を行う投 資のことを指す（Meenaghan, 1991b)。Meenaghan （1991b）の定義によると、企業のスポーツスポン サーシップの目的は利他的なものではなく、企業 とスポーツの関わりを深めることにより、様々 な便益を得ることと読み取れる。Howard and Crompton（2004）は、スポーツスポンサーシップ 契約におけるスポーツ組織と企業の関係性を理解 するのに交換理論を用いて説明している。交換理 論のもとで交換する条件として、まず、互いに相
手が欲する資産を保有し、それを交換することが 必要である。また、その交換する資産は同等の価 值であると相手より判断されなければならない。 よって、スポーツスポンサーシップ契約では、ス ポーツ組織は企業より金銭・製品・サービスを享 受し、それと同時に企業はスポーツ組織より同価 值と評価するブランドの露出、ブランドイメージ 向上、ホスピタリティの供与などの便益を受ける (Howard and Crompton, 2004)。このように、スポ ーツスポンサーシップは慈善活動とは違い、スポ ーツ組織と企業の双方に便益をもたらす必要があ り、この “win-win” シチュエーションを作りあげ ることが重要である。

\section{スポーツスポンサーシップの目的}

企業がスポーツスポンサーシップに投資する目 的は多岐にわたり、Sandler and Shani（1993）に よると、概ね次の三つの類型にわけられると報告 した。

- 企業の目的全般（企業の好意的なイメージ作り 等)

・マーケティング活動の目的（ブランドのプロモ ーション等活動)

・メディア活用の目的（費用効率が高いメディア の選択、標的市場への到達戦略等)

また、Lough et al. (2000) の研究によると、北 米企業（n=186）のスポンサーシップの目的は 次の 4 つの分野に収束される。

・関連企業とのネットワーク作り（関連企業との 関係向上）

・公共サービス（企業の社会貢献や従業員のモチ ベーション向上)

・企業地位の向上（企業イメージの向上や変化）

・ブランド優位性の向上（市場でのブランド認知 度、ブランドイメージ向上や売上増などの自ブ ランドの優位性を確保し、他ブランドとの差別 化を図る)

Lough et al.（2000）は、昨今の北米企業にとっ ては「ブランド優位性の向上」を目指したブラン ド認知度、ブランドイメージ向上や売上増など 
が一番重要であり、「公共サービス」に含まれる 社会的貢献が最も重要性が低かったと報告してい る。また、Walliser（2003）によるとスポンサー の目的はスポンサーの業界やスポンサーの規模に よって変わってくると報告している。日本におけ るスポンサー企業の目的は、Lough et al. (2000) の研究にて挙げられたものに類似すると思われる が、その重要性の比重は多少変わるであろう。

\section{スポーツスポンサーシップの特徵}

スポンサーシップが近年成長した理由として、 Madrigal（2001）や Rapp and Collins（1994）は広 告費の上昇、広告の増加や混雑度（クラッター） による効果減少懸念、伝統的な広告 (e.g., テレビ コマーシャル）に対する消費者の反応の変化、ビ ジネス関係の構築、細分化されたターゲット・オ ーディエンスに到達するためと報告している。こ のようなトレンドに押されて、欧米諸国では企業 はスポーツスポンサーシップ投資の比重を増やし てきた。

スポンサーシップは伝統的な広告と異なり、 様々な相違点が報告されている (Hastings, 1984; Meenaghan, 2001b)。例えば、広告は伝達するメ ッセージをコントロールし、率直に消費者に内容 を伝えることができるが、スポーツスポンサーシ ップによる広告看板の場合にはスペースの制限が あり、多くの内容は伝えられない (Crimmins and Horn, 1996; Hastings, 1984; Nebenzahl and Hornik, 1985)。また、広告はその媒体における範囲や枠 が決まっているが (e.g., テレビコマーシャル枠 は 15 秒や 30 秒など)、スポーツスポンサーシ ップの広告看板はスポーツ活動の背景で表示さ れ、その看板がテレビ中継で放映される時間は決 まっていない (Meenaghan, 1991a; Nebenzahl and Hornik, 1985; Pham, 1991)。よって、広告のメッ セージ伝達方法は直接的であるが、スポーツスポ ンサーシップのメッセージ伝達方法は間接的であ り、メッセージの解釈は視聴者に委ねられている (Meenaghan, 2001a)。

さらに Meenaghan（2001b）は、その一番の違
いは、スポーツスポンサーシップにおいて消費者 がスポンサー企業やブランドに対して抱く好意 としている。この好意は特にスポーツファン（チ ームファン）によるもので、企業のスポーツスポ ンサーシップ投資を、彼らの支持団体への金銭 的サポートと捉えているからである (Meenaghan, 2001b)。このスポンサー企業への好意的態度 (若しくは善意) は “Goodwill”と称され（他に “Reciprocity”や“Gratitude”とも表される)、ス ポーツスポンサーシップ投資は、ファンとの良 好な関係構築を目指す企業のマーケティング・ コミュニケーションの手段の 1 つとなっている (Bloxham, 1998; Meenaghan, 2001a, 2001b; Walliser, 2003)。

このようにスポーツスポンサーシップは、広告 同様、企業のマーケティング・コミュニケーショ ンの一環となり、企業の長期的戦略であるブラン ド・エクイティ（ブランド資産価值）構築の一翼 を担っている。

\section{スポーツスポンサーシップ研究}

近年スポーツスポンサーシップヘの関心が高 まり、企業が多額の資金をスポーツ組織に注ぎ 込んでいると同時に、実務家や研究者によってそ の定義、目的や効果などが研究されてきた（IEG， 2011; Lough et al., 2000; Pope, 1998; Sandler and Shani, 1993)。Cornwell and Maignan (1998) のス ポーツスポンサーシップ研究のレビューによる と、研究の動向として次の5つが挙げられている。

・スポーツスポンサーシップの特性の研究

・スポーツスポンサーシップの経営的側面の研究 ・スポーツスポンサーシップの効果測定の研究

・スポーツスポンサーシップの戦略的活用の研究 ・スポーツスポンサーシップの法的、または、倫 理的問題の研究

スポーツスポンサーシップの特性の研究は、主 にスポーツスポンサーシップの定義や特徴など を中心に論じられており、スポーツスポンサー シップの経営的側面の研究は企業のスポンサー シップの目的、意図などについて研究している。 
Lough et al. (2000) や Pope (1998) の研究もこ のカテゴリーに属する。スポーツスポンサーシ ップ効果測定研究は、いわゆる “ROI”（Return on Investment) や “ROO” (Return on Objectives) と 呼ばれる費用対効果の研究である。また、スポー ツスポンサーシップの戦略的活用の研究は、広 告や人的販売などを含めたスポーツスポンサーシ ップの戦略的展開や、アンブッシュ・マーケティ ングの研究が挙げられる。そして、スポーツスポ ンサーシップの法的と倫理的問題の研究は、タバ コなどの健康に害のある製品を扱うスポーツスポ ンサーシップの影響や、それらの法的制限など の研究である。このようにスポーツスポンサーシ ップの研究は様々であるが、多くの研究報告は消 費者への効果の解明を目的としたスポーツスポ ンサーシップの効果測定である (Cornwell, 1999; Cornwell and Maignan, 1998; Cornwell and Kwon, 2010; Walliser, 2003)。よって、ここからはスポー ッスポンサーシップの効果測定研究に焦点を当 て、その研究動向と課題について概説する。

\section{スポーツスポンサーシップの効果測定}

これまでのスポーツスポンサーシップの効果測 定は、テレビ等に代表されるメディアでの広告看 板露出時間の測定や消費者のスポンサー認知度、 スポンサーブランドイメージ形成、スポンサー製 品の購買決定プロセスなどを理解することに向 けられてきた（Walliser, 2003)。また、Cornwell et al. (2005) や Cornwell and Kwon (2010) は、最 近では、これらの研究をブランド・エクイティと いう概念的枠組みを用いて解明するものが多いと 報告している。ブランド・エクイティとは製品 やサービスに与えられる付加価值のことであり、 Aaker（1991）は、「ブランド名やロゴから連想さ れプラスの要素とマイナスの要素との総和（差し 引いて残る賞味の価值)」であると定義した（池 尾ほか, 2010, p.418)。つまり、それは消費者に とって無地のポロシャツとブランド・ロゴが入っ たポロシャツの間に感じる価值の差のことであ る。要するに企業は、ブランドに価值を与えるた
め独自の意味付けをし、顧客にその価值を提示し 強固な関係性を形成、維持することに努めている （池尾ほか，2010）。池尾ほか（2010）は、このブ ランド構築戦略を近年の企業の重要課題でもある と位置づけ、また、ブランド構築はマーケティン グ活動の手段の一つとしてではなく、それを念頭 においたマーケティング活動であり、さらには、 ブランドを起点としてのマーケティング活動とし て考えられてきていると報告した。Aaker（1991） は、ブランド・エクイティの構成要素は、ブラン ド認知、ブランド連想、知覚品質、ブランドロ イヤリティ、商標や特許などの法律的な制度の 5 つであると紹介した。また、Keller（1993）は顧 客視点からのブランド・エクイティを概念化し、 顧客のブランド認知とブランドイメージからなる ブランド知識の重要性を唱えた。

\section{1. 媒体露出時間測定方法}

スポーツスポンサーシップの効果測定方法とし て、当初は、ブランドの売上やメディアへの露出 時間を用いてきた（Cornwell and Maignan, 1998)。 しかし、ブランドの売上をスポーツスポンサーシ ップの効果とする方法は、他の販売促進活動や 過去の広告等の影響を受けている可能性がある ので、明確にスポーツスポンサーシップの効果と 断定できるものではないとされている（Bennett, 1999）。一方、メディアへの露出時間測定はテレ ビなどのメディアへのブランド・ロゴや広告看 板の露出時間や広告看板の大きさを測定し、合計 露出時間をテレビ広告費に換算したり、広告看 板の大きさを独自の指標で示したりして、それを スポーツスポンサーシップの効果とする方法で ある (Jones and Dearsley, 1989; Meenaghan, 1991b; Parker, 1991)。このようなテレビ広告費に換算す る等の方法は、数值で手っ取り早く示されるので 実務家に歓迎されるが (Cornwell, 2008)、問題点 も指摘されている。まず、Howard and Crompton （2004）は、スポーツスポンサーシップによる広 告看板の合計露出時間とテレビ広告の秒数を比較 すること自体が間違っていると報告している。こ の 2 つコミュニケーション手段は違った性質 
や目的があり、単純比較をするのは不適切である (Howard and Crompton, 2004)。また、この効果測 定方法は、あくまでもテレビなどの媒体での露出 時間を測定したものであって、視聴者や消費者に どのような効果があったかを示すデータではな い。つまり、この媒体露出時間測定方法は、消費 者の反応であるブランド認知度やブランドイメー ジ変容につながらず、研究者より批判されてきた (e.g., Pham, 1991; Quester and Farrelly, 1998)。

\section{2. ブランド認知}

ブランド認知の研究は、スポーツイベントに おけるスポンサーを再生法や再認法を利用して 視聴者、消費者の記憶を測定する研究である (e.g., Bennett et al., 2002; Cuneen and Hannan, 1993; Sandler and Shani, 1993; Stotlar and Johnson, 1989; Tsuji et al., 2009; Wakefield et al., 2007; Walsh et al., 2008)。再生法とは被験者にスポンサーを思い出 させる方法であり (e.g., 純粋想起、助成想起)、 一方、再認法はスポンサーのリストを見させて正 しいスポンサーを当てさせる記憶測定方法であ る。以前までのスポーツスポンサーシップ認知の 研究は、スポーツイベント参加者やテレビ視聴者 のスポンサー認知度を測定するのみで行われてい たが (e.g., Bennett et al., 2003; Pitts, 1998; Sandler \& Shani, 1993; Stotlar, 1993; Stotlar and Johnson, 1989)、最近の研究では Aaker（1991）のブランド・ エクイティ戦略、もしくは Keller（1993）の消費 者視点にたったブランド・エクイティの概念的枠 組みを用いて行なわれることが多い。Aaker(1991) と Keller（1993）は、消費者の購買決定プロセス の中で、ブランド認知があるだけで消費者行動に 影響を及ぼすと指摘している。特に、低関与の 製品に関しては、消費者はブランド名を知って いるからという理由だけで購買する場合もある と言われている（Dickson and Sawyer, 1986)。ま た、ブランドに対する態度が形成される前提条件 として消費者はブランドを認知していることが必 要であり、それなくしてはブランド態度やブラン ド購入意図などの形成はないとしている（Aaker, 1991; Keller, 1993, 2003, 2008; Macdonald and Sharp,
2003)。このように、近年のスポーツスポンサー シップ認知度の研究はブランド・エクイティの概 念的枠組みに関連づけて報告されている。

また、この認知度の研究で多く報告されている のが消費者行動の情報処理の観点からの研究であ る。つまり、消費者がスポンサーを思い出す過程 で、どのような思考でスポンサーを思い出すかを 解明する研究である。Johar and Pham (1999) と Pham and Johar（2001）によると、視聴者や消費 者がスポンサーを思い出す時に、第一に純粋想起 に頼るが、思い出せない時には、有名なブランド (prominence) やスポーツイベントのイメージと 一致する (congruence) ブランドをスポンサーと して回答すると報告している。また、他の研究で は視聴者や消費者のスポーツやチーム、イベント などとの永続的関与 (enduring involvement)、一 時的関与 (situational involvement)、興奮 (arousal)、 スポーツ、または、チームアイデンティフィケー ション (sport identification, team identification)、ス ポーツイベントとスポンサーのイメージの一致 (congruence)、スポーツイベントとスポンサーの 関連性の説明 (articulation) などによる認知度へ の影響を報告している (e.g., Cornwell et al., 2006; d'Ydewalle et al., 1988; Grohs et al., 2004; Koo et al., 2006a, 2006b; Lardinoit and Derbaix, 2001; Levin et al., 2001; Pham, 1992; Tavassoli et al., 1995; Tsuji et al., 2009)。このように様々な観点からスポーツス ポンサーシップの認知度の研究が行われてきた。

\section{3. ブランドイメージ}

次に注目を集めているスポーツスポンサーシッ プの効果測定研究のテーマは、スポンサーブラン ドイメージである。ブランドイメージやブラン ドに対する態度が重要視される理由は、それら がその後の購買意図や実際の購買などにつながる とされているからである (Ajzen, 1991; Eagly and Chaiken, 1993; Lutz, 1991)。Meenaghan (2001b) によるとスポーツイベントにおけるブランドイメ ージやブランドに対する態度形成は、ファンのス ポーツチームへの関与 (fan involvement) とファ ンの企業への善意、好意 (goodwill) が関係して 
いる。ファンのチームへの関与レベルが高いほど、 彼らはその行為に対して多大な善意や好意を企 業に対して抱くことがわかっている（Meenaghan, 2001b)。このように、企業はスポーツスポンサー シップを通じてファンの好意的態度を獲得するこ と、さらに、購買してもらうように目指している (e.g., Choi et al., 2011; Dees et al., 2008; Dees et al., 2010b)。また、スポーツスポンサーシップに関わ るイメージ調査（e.g., イベントに対する態度、ス ポーツの商業化に対する態度、スポンサー製品の 購入意図に対する態度）を行った研究例も報告さ れている (e.g., Dees and Bennett, 2008; Dees et al., 2007; Lee et al., 1997)。

続いてのイメージに関する研究は、スポーツの イメージがブランドイメージへ転移（イメージ・ トランスファー、ミーニング・トランスファー) する効果について検討したものである。Gwinner （1997）によると、スポーツイベントのイメージ は次の要素から成ると報告した。

- スポーツの種類

・スポーツイベントの特徴（プロ／アマチュア、 施設の種類、イベント大きさ等)

・イベントに参加する顧客によって生じる要因 （過去のイベント参加経験等）

要するに、スポンサーはスポーツスポンサーシ ップを通じてスポーツやチームが保有する特有の イメージがブランドに転移する効果を期待してい る (Crimmins and Horn, 1996; Gwinner and Eaton, 1999; Meenaghan and Shipley, 1999; Meenaghan, 2001a; Quester and Farrelly, 1998)。例えば、紳士 的で高級なイメージのあるゴルフを企業がスポン サーすると、企業は自社ブランドにゴルフの高級 なイメージが転移することが期待できる。

このイメージの転移は、Heider (1958) のバラ ンス理論 (balance theory) や McCracken (1989) の有名人推奨モデル (celebrity endorsement model) を使って説明されることが多い (Cornwell et al., 2005)。バランス理論では、消費者はバランスの 取れた解釈を好み、組み合わされた二者の一方の イメージが悪く、片一方が良い場合では、バラン スを保つため、いずれかのイメージを修正する
傾向がある。つまり、スポーッスポンサーシッ プに当てはめると、ある消費者にとってスポンサ ーのイメージが悪く、スポーツ組織のイメージ が良い場合は、不均衡が生じ、消費者はそれを是 正しょうとスポーツ組織かスポンサーのイメー ジをいずれかの方向に修正するのである。また、 McCracken（1989）のモデルを適応すると、スポ ーツ組織のイメージを保有している消費者は、ス ポンサーシップ契約によって企業と結ばれると、 そのイメージを転移する傾向にあると報告してい る。

Howard and Crompton（2004）はブランドが保 有するイメージがスポーツやチームに転移するこ とも可能であると説明している (e.g., フーリガン の問題を抱えていたイギリスのプレミアリーグは 礼儀正しい、秩序だったイメージを持つバークレ イズバンクをタイトルスポンサーとして迎えるこ とによりイメージチェンジを図った)。また、こ のイメージの転移はスポーツイベントのイメージ とブランドイメージのフィット（一致）が起これ ば転移しやすいことがわかっている（Crimmins and Horn, 1996; Gwinner and Eaton, 1999; Howard and Crompton, 2004; Stipp and Schiavone, 1996)。 Gwinner and Eaton (1999) は、スポーツイベント やチームとスポンサーの機能的な一致（e.g., タイ ヤメーカーと Formula-1) やイメージの一致 (e.g., 伝統的なイメージと野球、斬新性とアクションス ポーツなど）があるとイメージが転移すると報告 している。

このスポンサーとスポーツイベント、若しく は、チームのイメージとのフィットとその効果を 検証する研究では、ブランド認知やイメージ転移 以外にも様々な効果があると報告されている。こ のフィットは、一致理論 (congruence theory) や スキーマ理論（schema theory）を用いて関係性が 説明されることが多い (Cornwell et al., 2005)。一 致理論ではスポンサーを記憶から思い出す時は、 関係性や類似性のある方がより良く思い出せると している (Cornwell, et al., 2005)。またスキーマ 理論では、消費者にはスキーマと呼ばれる過去の 経験に基づく構造化された知識があり、それを用 
いて消費者はスポンサーとスポーツイベントのフ イットを考える（McDaniel, 1999; Roy \& Cornwell, 2004）。つまり、消費者は新しい情報を処理する 際、スポンサーとスポーツイベントのスキーマ を呼び起こし、新しい情報と比べてイメージの一 致があるかを判断する (Roy and Cornwell, 2004)。 このフィットが消費者に認識されるとスポンサー への好意的な態度や購入意図へとつながり（e.g., Koo et al., 2006a; McDaniel, 1999; Rifon et al., 2004; Speed and Thompson, 2000)、逆に消費者にイメー ジのフィットが認識されないとスポンサーに対す る意見や態度にマイナスの効果が生じると報告さ れている (Becker-Olsen and Simmons, 2002)。イ メージのフィットに関する研究には、スポーッ イベントとスポンサーのフィット以外にも、スポ ーツとスポンサーのフィット (e.g., Musante et al., 1999）などがあり、Gwinner and Bennett（2008） や山口ほか (2010) はブランドフィットに影響を 及ぼす要因の研究を報告している。

また、イメージに関するスポーツスポンサー シップ研究に、Aaker（1997）のブランド・パー ソナリティの概念的枠組みを用いた研究例があ る。ブランド・パーソナリティとは、ブランドを 人間に喻えたときに保有する人格や性格のこと である（Aaker, 1997)。Aaker（1997）によると、 ブランド・パーソナリティには 5 つの因子があ り、それぞれ誠実 (sincerity)、刺激（excitement）、 能力 (competence)、洗練 (sophistication) 素朴 (ruggedness) と命名した（利根川, 2008)。Lee and Cho (2007) は、同様にスポーツイベントが 人格を有するとして捉え、スポーツイベント・パ ーソナリティを検証した。スポーツイベント・パ ーソナリティは 5つの因子より成り、それぞれ勤 勉 (diligence)、無制約 (uninhibitedness)、強壮 (fit)、 伝統 (tradition)、娛楽 (amusement) と名付けた (Lee and Cho, 2007)。また、そのスポーツイベン ト・パーソナリティとブランド・パーソナリティ とのイメージフィットを検証した研究も報告され ている (Lee and Cho, 2009)。Dees et al. (2010a)は、 Aaker（1997）のブランド・パーソナリティの尺 度を用いて米国の “National Association for Stock
Car Auto Racing” (NASCAR) のドライバーのパ ーソナリティとスポンサーブランド・パーソナリ ティのフィットがスポンサー態度や購入意図に及 ぼす影響を検証した。また、Heere（2010）は消 費者視点のブランド・パーソナリティではなく、 スポーツチームの経営者が意図するブランド・パ ーソナリティの分析を行った。

\section{スポーツスポンサーシップ効果測定研究の 課題}

このように多くのスポーツスポンサーシップ 効果測定の研究が報告がされているが、Cornwell （1999）や Cornwell and Maignan（1998）によると、 スポーツスポンサーシップ研究のなかには理論を 用いずスポーツスポンサーシップ効果の解明を行 なっている研究も一部あると指摘している。そこ で、Cornwell et al. (2005) は過去の研究のレビュ 一を行い、スポーツスポンサーシップ効果に影響 を与える要因と使用された理論を明らかにした。 Cornwell et al. (2005) によると、スポーツスポン サーシップ効果に影響する要因は次の三つであ る。

・個人及びグループによる要因（過去の経験、知 識、関与、社会アライアンス)

・マーケット要因（ブランド・エクイティ、クラ ッター、競合状況 $)$

・マネジメント要因（スポンサーシップ政策、ア クティベーション、レバレッジ)

つまり、各要因が消費者の情報処理プロセス(理 論）にそれぞれ影響を与え、消費者の認知的、態 度的、行動的反応を惹き起こすと報告した（表 1)。 このように、現在まで様々な理論を用いてスポー ツスポンサーシップ研究が展開されてきたが、今 後もスポンサーシップ効果を理解するためにも理 論を用いた研究が求められている。

Cornwell et al.（2005）は、スポーツスポンサー シップ効果の研究メソッドについても言及してい る。一般的なマーケティング戦略では、スポーツ スポンサーシップという媒体のみで消費者に情報 伝達するわけではなく、多種多様な媒体、方法を 
表 1 Cornwell et al.（2005）のスポーツスポンサーシップ研究の理論的枠組み

\begin{tabular}{lll}
\hline & \multicolumn{1}{c}{ 理論 } & \multicolumn{1}{c}{ 先行研究 } \\
\hline Mere exposure effect & 単純接触効果 & Bennett, 1999 \\
\hline Low-level processing & 精緻化見达みモデル—周辺的態度変化 & Olson and Thjømøe, 2003 \\
\hline Reactivation & 再活性化 & Pham and Vanhuele, 1997 \\
\hline Matching/Congruence & マッチング・一致 & Gwinner and Eaton, 1999; Johar and Pham, 1999; Johar \\
Articulation & 関連性の説明 & et al., 2006; McDaniel, 1999 \\
\hline Balance/Meaning transfer & イメージ転移 & Cornell et al., 2006 \\
\hline Identification & アイデンティフィケーション & $\begin{array}{l}\text { Gwinner and Eaton, 1999; Johar and Pham, 1999; Johar } \\
\text { et al., 2006; McDaniel, 1999 }\end{array}$ \\
\hline Classical conditioning & 古典的条件付け & Madrigal, 2001 \\
\hline Prominence heuristic & 経験則 & Speed and Thompson, 2001 \\
\hline Attribution theory & 帰属理論 & Johar and Pham, 1999; Johar et al., 2006; Pham and \\
\hline
\end{tabular}

用いて訴求していく。よって、他のプロモーショ ン効果がブランド認知やブランドイメージ向上に 影響をしていることが考えられる。この理由より 真のスポーツスポンサーシップ効果をフィールド で測るのは難しいと指摘されている（Cornwell et al., 2005; Pham, 1991)。したがって、真のスポー ツスポンサーシップ効果を測定するには実験を用 いて、他の効果を無効化する必要がある (Pham, 1991)。また、Johar et al. (2006) や Wakefield et al. (2007) の研究のように、実験の結果（Johar and Pham, 1999; Pham and Johar, 1997, 2001）に基 づいたフィールドにおける研究も今後のスポーツ スポンサーシップの効果測定の研究では重要であ る。

\section{終わりに}

企業がスポーツスポンサーシップに投資する目 的は、もはや社会貢献ではなく、ビジネス目的を 念頭において、視聴者やスポーッファンとのコミ ユニケーションへと変遷した。また、スポーツス ポンサーシップの形態は常に変化を続け、もはや 広告看板のみではなく、多岐にわたって企業とス ポーツ組織で契約がかわされているのが現状であ る。よって、スポーツ組織はスポンサーのニーズ を理解し、互いに便益を得られる友好関係を築く
ために努力をしなければならない。

研究者としては、この変わり続ける形態を充分 に把握し、スポーツスポンサーシップという現象 の理解に努める必要がある。今までのスポーツス ポンサーシップ研究の多くはスポーツスポンサー シップ効果を主に行なわれてきたが、それ以外に も、Lough et al. (2000) の研究でいう「関連企業 とのネットワーク作り」(関連企業との関係構築) や、「公共サービス」所謂、内なる顧客（従業員） に目をむけた研究も（e.g., Hall et al., 2009）検討 すべきである。また、Cornwell and Maignan (1998) が紹介した効果測定以外の領域の研究や別の観点 からみた (e.g., ファイナンス、会計学) スポーツ スポンサーシップの研究も必要である。さらに、 研究を遂行するにあたって、他の絵画、慈善運動、 フェスティバルなどのスポンサーシップ研究も参 考にするのも重要と思われる。

最後に、この論文ではスポーツスポンサーシッ プの実態、その研究と効果測定方法を中心に報告 したが、取り上げた文献は一部であり、全ての研 究を網羅したわけではない。今後スポーツスポン サーシップ研究を進めていくにあたっては、ここ に挙げた文献以外も参照されたい。また、スポー ツスポンサーシップ研究が企業側の視点のみなら ず、スポーツ側からの視点からも行なわれ、スポ ーツ界の発展に貢献することを願う。 


\section{【文献】}

Aaker, D. A. (1991) Managing brand equity. The Free Press: New York, NY, USA.

Ajzen, I. (1991) The theory of planned behavior. Organizational Behavior and Human Decision Processes, 50: 179-211.

Becker-Olsen, K., and Simmons, C. J. (2002) When do social sponsorships enhance or dilute equity? Fit, message source, and the persistence of effects. Advances in consumer research, 29: 287-289.

Bennett, G., Henson, R., and Zhang, J. (2002) Action sports sponsorship recognition. Sport Marketing Quarterly, 11: 185-196.

Bennett, R. (1999) Sports sponsorship, spectator recall and false consensus. European Journal of Marketing, 33: 291-313.

Bloxham, M. (1998) Brand affinity \& television programme sponsorship. International Journal of Advertising, 17: 89-98.

Choi, J. H., Tsuji, Y., Hutchinson, M., and Bouchet, F. A. (2011) An investigation of sponsorship implications within a state sports festival: The case of the Florida Sunshine State Games. International Journal of Sports Marketing and Sponsorship, 12: 108-123.

Cornwell, T. B. (1999) Recent developments in international sponsorship research. Sponsorship Business Review, 2: 36-42.

Cornwell, T. B. (2008) State of the art and science in sponsorship-linked marketing. Journal of Advertising, 37(3): 41-55.

Cornwell, T. B., Humphreys, M. S., Maguire, A., Weeks, C. S., and Tellegen, C. L. (2006) Sponsorship-linked marketing: The role of articulation in memory. Journal of Consumer Research, 33: 312-321

Cornwell, T. B., and Kwon, Y. (2010) Another decade of sponsorship research reviewed. Paper presented at the 25th North American Association for Sport Management Conference. Tampa, FL.

Cornwell, T. B., and Maignan, I. (1998) An international review of sponsorship research. Journal of Advertising, 27(1): 1-21.

Cornwell, T. B., Weeks, C. S., and Roy, D. P. (2005) Sponsorship-linked marketing: Opening the black box. Journal of Advertising, 34(2): 21-42.

Crimmins, J., and Horn, M. (1996) Sponsorship: From management ego trip to marketing success. Journal of Advertising Research, 36(4): 11-21.

Cuneen, J., and Hannan, M. (1993) Intermediate measures and recognition testing of sponsorship at an LPGA Tournament. Sport Marketing Quarterly, 2(1): 47-56.

Dean, D. H. (2002) Associating the corporation with a charitable event through sponsorship: Measuring the effects on corporate community relations. Journal of Advertising, 31(4): 77-87.

Dees, W., and Bennett, G. (2008). The effect of fan involvement on consumers' response to sponsorship at a professional tennis tournament. International Journal of Sport Management, 9(3): 1-15.

Dees, W., Bennett, G., and Ferreira, M. (2010a) Personality fit in NASCAR: An evaluation of driver-sponsor congruence and its impact on sponsorship effectiveness outcomes. Sport Marketing Quarterly, 19: 25-35.

Dees, W., Bennett, G., and Tsuji, Y. (2007) Attitudes toward sponsorship at a state sports festival. Event Management, 10: 89-101.

Dees, W., Bennett, G., and Villegas, J. (2008) Measuring the effectiveness of sponsorship of an elite intercollegiate football program. Sport Marketing Quarterly, 17: 79-89.

Dees, W., Hall, T., Tsuji, Y., and Bennett, G. (2010b) Examining the effects of fan loyalty and goodwill on consumer perceptions of brands at an action sports event. Journal of Sponsorship, 4: 38-50.

Dickson, P. R., and Sawyer, A. G. (1986) Point-of-purchase behavior and price perceptions of supermarket shoppers. Marketing Science Institute: Cambridge, MA, USA.

d'Ydewalle, G., Abeele, P. V., Van Rensbergen, J., and Coucke, P. (1988) Incidental processing of advertisements while watching soccer games broadcasts. In: Gruneberg, M., Morris, P., and Sykes, R. (Eds.) Practical aspects of memory: Current research and issues. John Wiley \& Sons: New York, NY, USA, pp. 478-483.

Eagly, A. H., and Chaiken, S. (1993) The psychology of attitudes. Harcourt Brace Jovanovich College Publishers: New York, NY, USA.

Grohs, R., Wagner, U., and Vsetecka, S. (2004) Assessing the effectiveness of sport sponsorships: An empirical examination. Schmalenbach Business Review, 56: 119-138.

Gwinner, K. (1997) A model of image creation and image transfer in event sponsorship. International Marketing Review, 14: 145-158.

Gwinner, K., and Bennett, G. (2008) The impact of brand cohesiveness and sport identification on brand fit in a sponsorship context. Journal of Sport Management, 22: 410-426.

Gwinner, K. P., and Eaton, J. (1999) Building brand image 
through event sponsorship: The role of image transfer. Journal of Advertising, 28(4): 47-57.

Hall, T., Ferreira, M., and Sagas, M. (2009) Sponsorship and the internal audience: Examining how corporate sponsorship is related to organization identification and job satisfaction. Paper presented at the 7 th annual Sport Marketing Association conference. Cleveland, $\mathrm{OH}$.

Hastings, G. B. (1984) Sponsorship works differently from advertising. International Journal of Advertising, 3: 171-176.

Heider, F. (1958) The psychology of interpersonal relations. Wiley: New York, NY, USA.

Heere, B. (2010) A new approach to measure perceived brand personality associations among consumers. Sport Marketing Quarterly, 19: 17-24.

Howard, D. R., and Crompton, J. L. (2004) Financing Sport (2nd ed.). FIT: Morgantown, WV, USA.

IEG (2011) Sponsorship spending recedes for first time; better days seen ahead. Retrieved April 9, 2011 from http://www.sponsorship.com/extra/iegsr/IEGSR2011_Sp endingProjections.pdf.

池尾恭一・青木幸弘・南知恵子・井上哲浩（2010） マーケティング. 有斐閣 : 東京.

Johar, G. V., and Pham M. T. (1999) Relatedness, prominence, and constructive sponsor identification. Journal of Marketing Research, 36: 299-312.

Johar, G. V., Pham, M. T., and Wakefield, K. L. (2006) How event sponsors are really identified: A (baseball) field analysis. Journal of Advertising Research, 46: 183-198.

Jones, M., and Dearsley, T. (1989) Understanding sponsorship. In: Meenaghan, T. (Ed.) Researching commercial sponsorship. ESOMAR: Amsterdam, Netherlands, pp.41-54.

Keller, K. L. (1993) Conceptualizing, measuring, and managing customer-based brand equity. Journal of Marketing, 57(1): 1-22.

Keller, K. L. (2003) Brand synthesis: The multidimensionality of brand knowledge. Journal of Consumer Research, 29: 595-600.

Keller, K. L. (2008) Strategic brand management (3rd ed.). Pearson Education, Inc: Upper Saddle River, NJ, USA.

Koo, G. Y., Quarterman, J., and Flynn, L. (2006a) Effect of perceived sport event and sponsor image fit on consumers' cognition, affect, and behavioral intentions. Sport Marketing Quarterly, 15: 80-90.

Koo, G. Y., Quarterman, J., and Jackson, N. E. (2006b) The effect of perceived image fit on brand awareness: 2002 Korea-Japan World Cup. International Journal of Sports
Marketing and Sponsorship, 7: 180-191.

Lardinoit, T., and Derbaix, C. (2001) Sponsorship and recall of sponsors. Psychology \& Marketing, 18: 167-190.

Lee, H. S., and Cho, C. H. (2007) Sporting event personality: Scale development and sponsorship implications. Paper presented at the 2007 conference of the American Academy of Advertising, Burlington, VT.

Lee, H. S., and Cho, C. H. (2009) The matching effect of brand and sporting event personality: Sponsorship implications. Journal of Sport Management, 2009, 23: 41-64.

Lee, M. S., Sandler, D. M., and Shani, D. (1997) Attitudinal constructs towards sponsorship: Scale development using three global sporting events. International Marketing Review, 14: 159-169.

Levin, A. M., Joiner, C., and Cameron, G. (2001) The impact of sports sponsorship on consumers' brand attitudes and recall: The case of NASCAR fans. Journal of Current Issues and Research in Advertising, 23(2): 23-31.

Lough, N. L., Irwin, R. L., and Short, G. (2000) Corporate sponsorship motives among North American companies: A contemporary analysis. International Journal of Sport Management, 1: 283-295.

Lutz, R. J. (1991) The role of attitude theory in marketing. In: Kassarjian, H. H., and Robertson, T. S. (Eds.) Perspectives in consumer behavior. Prentice Hall: Englewood Cliffs, NJ, USA, pp. 317-339.

Macdonald, E., and Sharp, B. (2003) Management perceptions of the importance of brand awareness as an indication of advertising effectiveness. Marketing Bulletin, 14: 1-11.

Madrigal, R. (2001) Social identity effects in a beliefattitude-intentions hierarchy: Implications for corporate sponsorship. Psychology \& Marketing, 18: 145-165.

Marketing fact book (2005) Events \& sponsorships. Marketing News,39(12): 30 .

McCracken, G. (1989) Who is the celebrity endorser? Cultural foundation of the endorsement process. Journal of Consumer Research, 16: 310-321.

McDaniel, S. R. (1999) An investigation of match-up effects in sport sponsorship advertising: The implications of consumer advertising schemas. Psychology \& Marketing, 16: 163-184.

Meenaghan, T. (1991a). Sponsorship: Legitimising the medium. European Journal of Marketing, 25(11): 5-10.

Meenaghan, T. (1991b) The role of sponsorship in the marketing communications mix. International Journal of 
Advertising, 10: 35-47.

Meenaghan, T. (2001a) Sponsorship and advertising: A comparison of consumer perceptions. Psychology \& Marketing, 18: 191-215.

Meenaghan, T. (2001b) Understanding sponsorship effects. Psychology \& Marketing, 18: 95-122.

Meenaghan, T., and Shipley, D. (1999) Media effect in commercial sponsorship. European Journal of Marketing, 33: 328-347.

Musante, M., Milne, G. R., and McDonald, M. A. (1999) Sport sponsorship: Evaluating the sport and brand image match. International Journal of Sports Marketing \& Sponsorship, 1: 32-48.

Nebenzahl, I., and Hornik, J. (1985) An experimental study of the effectiveness of commercial billboards in televised sports arenas. International Journal of Advertising, 4: 27-36.

Olson, E. L., and Thjømøe, H. M. (2003) The effects of peripheral exposure to information on brand performance. European Journal of Marketing, 37: 243-255.

Parker, K. (1991) Sponsorship: The research contribution. European Journal of Marketing, 25(11): 22-30.

Pham, M. T. (1991) The evaluation of sponsorship effectiveness: A model and some methodological considerations. Gestion 2000, 4: 47-65.

Pham, M. T. (1992) Effects of involvement, arousal, and pleasure on the recognition of sponsorship stimuli. Advances in Consumer Research, 19: 85-93.

Pham, M. T., and Johar, G. V. (1997) Contingent processes of source identification. Journal of Consumer Research, 24: 249-265.

Pham, M. T., and Johar, G. V. (2001) Market prominence biases in sponsorship identification: Processes and consequentiality. Psychology \& Marketing, 18: 123-143.

Pham, M. T., and Vanhuele, M. (1997) Analyzing the memory impact of advertising fragments. Marketing Letters, 8: 407-417.

Pitts, B. G. (1998) An analysis of sponsorship recall during Gay Games IV. Sport Marketing Quarterly, 7(4): 11-18.

Pope, N. (1998) Overview of current sponsorship thought. Cyber Journal of Sport Marketing, 2(1), Retrieved March 22, 2006, from http://www.ausport.gov.au/fulltext/1998/ cjsm/v2n1/pope21.htm

Quester, P. G., and Farrelly, F. (1998) Brand association and memory decay effects of sponsorship: The case of the Australian Formula One Grand Prix. Journal of Product \& Brand Management, 7: 539-556.
Rapp, S., and Collins, T. L. (1994) Beyond maxi-marketing. McGraw-Hill: New York, NY, USA.

Rifon, N. J., Choi, S. M., Trimble, C. S., and Li, H. (2004) Congruence effects in sponsorship: The mediating role of sponsor credibility and consumer attribution of sponsor motive. Journal of Advertising, 33(1): 29-42.

Roy, D. P., and Cornwell, T. B. (2004) The effects of consumer knowledge on responses to event sponsorships. Psychology \& Marketing, 21: 185-207.

Sandler, D., and Shani, D. (1993) Sponsorship and the Olympic Games: The consumer perspective. Sport Marketing Quarterly, 2(3): 38-43.

Speed, R., and Thompson, P. (2001) Determinants of sports sponsorship response. Journal of the Academy of Marketing Science, 28: 226-238.

Stipp, H., and Schiavone, N. P. (1996) Modeling the impact of Olympic sponsorship on corporate image. Journal of Advertising Research, 36(4): 22-28.

Stotlar, D. K. (1993) Sponsorship and the Olympic Winter Games. Sport Marketing Quarterly, 2(1): 35-43.

Stotlar, D. K., and Johnson, D. A. (1989) Assessing the impact and effectiveness of stadium advertising on sport spectators at Division 1 institutions. Journal of Sport Management, 3: 90-102.

Tavassoli, N. T., Shultz, C. J., and Fitzsimons, G. J. (1995) Program involvement: Are moderate levels best for ad memory and attitude toward the ad? Journal of Advertising Research, 35(5): 61-72.

利根川孝一（2008）ブランド戦略分析のための統合 モデル：ブランド・パーソナリティを応用して. 日本情報経営学会誌, 28(3): 23-33.

Tsuji, Y., Bennett, G., and Leigh, J. H. (2009) Investigating factors affecting brand awareness of virtual advertising. Journal of Sport Management 23: 511-544.

Wakefield, K. L., Becker-Olsen, K., and Cornwell, T. B. (2007) I spy a sponsor: The effects of sponsorship level, prominence, relatedness and cueing on recall accuracy. Journal of Advertising, 36(4): 61-74.

Walliser, B. (2003) An international review of sponsorship research: Extension and update. International Journal of Advertising, 22: 5-40.

Walsh, P., Kim, Y., and Ross, S. D. (2008) Brand recall and recognition: A comparison of television and sport video games as presentation modes. Sport Marketing Quarterly, 17: 201-208.

山口志郎・野川春夫・北村薰・山口泰雄（2010） ス ポーツイベントのスポンサーシップにおけるスポ ンサーフィットに関する研究 : Gwinner and Bennett 
スポーツマネジメント研究 第 3 巻第 1 号

モデルの検証. スポーツマネジメント研究，2：

147-161.

$\left(\begin{array}{c}2011 \text { 年 } 1 \text { 月 } 19 \text { 日受付 } \\ 2011 \text { 年 } 7 \text { 月 } 19 \text { 日受理 }\end{array}\right)$ 